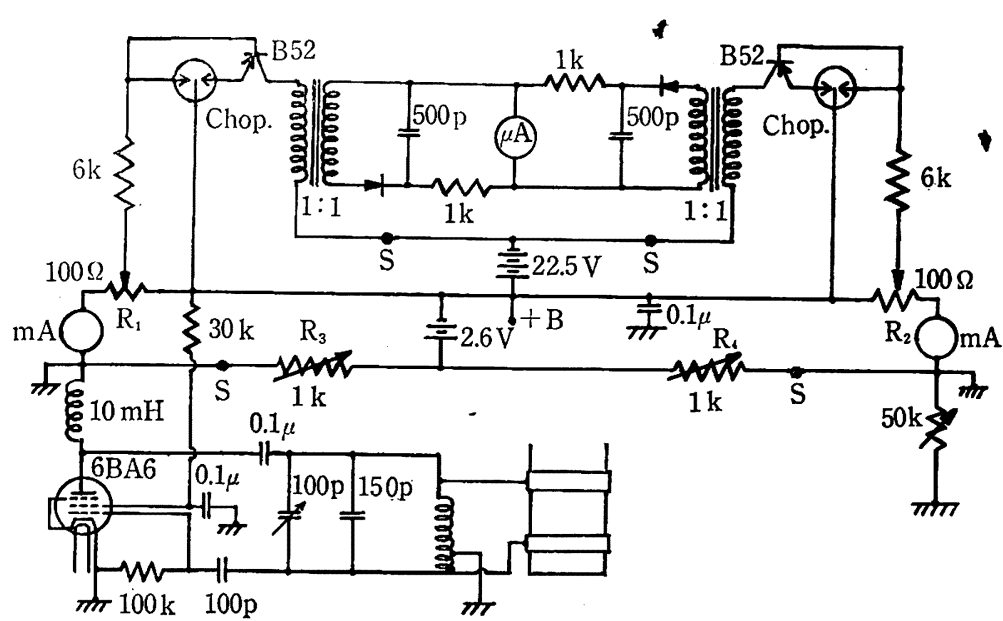

図 3 高周波滴定装置回路図

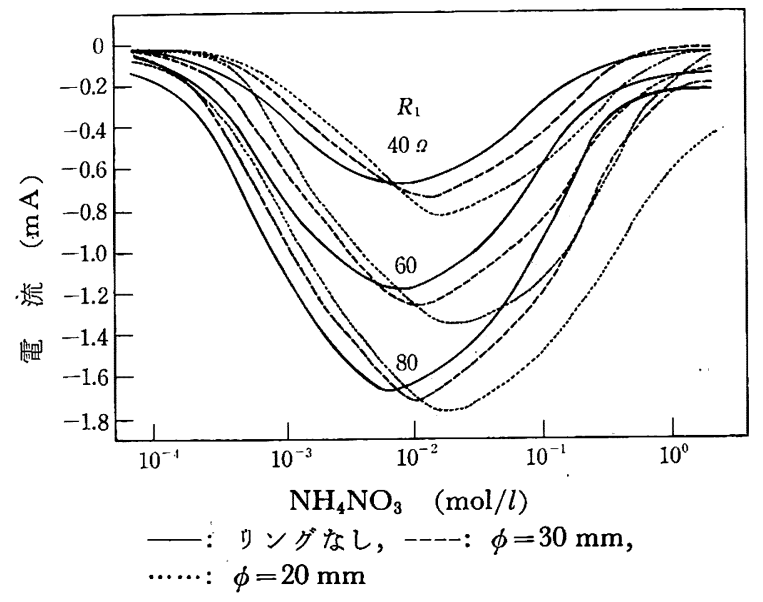

図 4 ゴムリング使用および増幅変化による基礎曲線変化の例
り， $R_{1}$ が同じとき $\phi$ の小さい方が極点が哚くなっていることに 現われている。

\section{4 結・語}

容器中にゴムリングを抙入して 電流の経路を長くする(あるい は断面を絞る)ことにより，基礎曲線の傾斜部分を 濃厚域へある 程度移動させることができた。この方法は容器壁を薄くしたり, 電極間隔を離したり，周波数を変化させるなど装置に手を加える ことなしに調節のできる簡便な方法である。また測定電流の変化 分を増幅して曲線の深さ(感度)を任意に調節できる簡単な回路を 試作した。これらによりコイル型との組み合わせの操作が容易に なるとともに，コンデンサ型単独で使用するときにも役立つるの と考えられる。

(1967 年 10 月，日本化学会中国四国大会発表)

\title{
$\boldsymbol{N}, \boldsymbol{N}$-二置換アミノェタノールの Schotten-Baumann 反応
}

（昭和 42 年 11 月 8 日受理)

大城 禧 一・尾”形強・吉 田弘・猪川 三 郎*1

\section{1 緒 言}

既報1 に打いて，著者らは 2-ジエチルアミノエタノール $\left(\mathrm{C}_{2} \mathrm{H}_{5}\right)_{2} \mathrm{NCH}_{2} \mathrm{CH}_{2} \mathrm{OH}$ を Schotten-Baumann 反応を用いて, ベ ンゾィル化すると，相当するエステルの安息香酸塩と，その他に 多量の無水安息香酸が生成することを見いだして報告した。さら に，この反応を詳細に検討したところ，エステルの安息香酸塭 $\left(\mathrm{C}_{2} \mathrm{H}_{5}\right)_{2} \stackrel{\oplus}{\mathrm{N}} \mathrm{HCH}_{2} \mathrm{CH}_{2} \mathrm{OCOC}_{6} \mathrm{H}_{5} \cdot \mathrm{C}_{6} \mathrm{H}_{5} \mathrm{COO} \ominus$ が㶵水安息香酸生 成の中間体であるここがわかり報告した。

*1 Kiichi Oshiro, Tsuyoshi Ogata, Hiroshi Yoshida, Saburo INOKAWA 静岡大学工学部合成化学科, 浜松市 城北

1) T. Ogata et al., Bull. Chem. Soc. Japan, 40, 997 (1967)
本報ではジェチルアミノ基をその他の第三級アうノ基にかえた 場合，同じような現象がみられるかどうかを検討した結果につい て報告する。本実験に用いたアミノエタノールはジベンジルアミ ノェタノール[1]， シクロヘキシルフェニルアミノェタノール [2], モルホリノエタノール[3], ジシクロヘキシルアミノエタ ノール[4], ジメチルアミノエタノール[5], ピロリジノエタ, ール[6]，およびピペリジノエタノール[7]である。

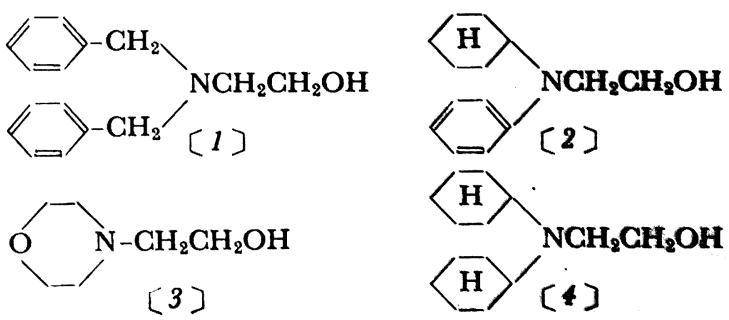


$\stackrel{\mathrm{CH}_{3}}{\mathrm{CH}_{3}}>\mathrm{NCH}_{2} \mathrm{CH}_{2} \mathrm{OH}$

[5]<smiles>OCCN1CCC1</smiles>

[6]
N- $-\mathrm{CH}_{2} \mathrm{CH}_{2} \mathrm{OH}$

\section{2 実験}

\section{1 試 薬}

$\boldsymbol{N}, \boldsymbol{N}$-二置換アミノエタノール : [1 $\left.]^{2}\right),[2]^{3)},[3]^{4)},[4]^{2)}$,

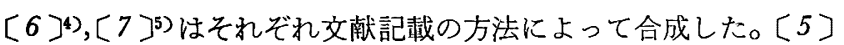
は市肘品を常法によって精製して使用した。それらの性質を表 1 に示す。

\section{表１ $N, N$-二置換丁ミノェタノールの性質}

\begin{tabular}{cccc} 
化合物 & $\begin{array}{c}{ }^{\circ} \text { 沸 点 } \\
\left({ }^{\circ} \mathrm{C} / \mathrm{mmHg}\right)^{a)}\end{array}$ & \multicolumn{1}{c}{$n_{\mathrm{D}}{ }^{b)}$} & $\begin{array}{c}\text { ピクラートの } \\
\text { 融点 }\left({ }^{\circ} \mathrm{C}\right)^{a)}\end{array}$ \\
{$[1]$} & $195 / 8(195 / 8)$ & $1.5618(29)$ & - \\
{$[2]$} & $184 \sim 186 / 20$ & - & - \\
{$[3]$} & $222(222)$ & $1.4755(22)$ & $125 \sim 125.5$ \\
{$[4]$} & $189 / 20$ & $1.4960(28)$ & - \\
{$[5]$} & $13.4(135)$ & $1.4290(20)$ & $96(96 \sim 97)$ \\
{$[6]$} & $184 \sim 186(184 \sim 186)$ & $1.4685(25.5)$ & $76 \sim 77(76)$ \\
{$[7]$} & $199 \sim 200(199)$ & $1.4740(16)$ & $100.5 \sim 101.5$
\end{tabular}

注 $a$ ) 沸点, 融点の（）内は交献值を示す.

b) ( ) 内は測定温度 $\left({ }^{\circ} \mathrm{G}\right)$ を示す。

塩化ベンゾイル：市販品をそのまま使用した。

\section{2 実験方法}

交献6に準じて行なった。すなわち，アミノエタノール類 0.05 $\mathrm{mol}$ を $10 \%$ 水酸化ナトリウム水溶液 $(210 \mathrm{~g})$ に溶解し, 液温を $0^{\circ} \mathrm{G}$ 前後にたもち，かきまぜながら徐々に塩化ベンゾイル 0.25 mol を滴下し, 滴下後さらに約 2 時間かきまぜて反応を完結させ た。反応終了後, 油層をエーテルで抽出し, 水層とわけ, 水層か らは連続的なエーテル抽出によって未反応アミノエタノールが得 られた。また，水層を塩酸で中和することによって安息香酸が得 られた。エーテル抽出部からはエーテル留去後減圧蒸留するとと にようでステル*2，または無水安息香酸が得られた。

\section{$2.3 p K_{a}$ の測定}

滴定法》によって，生成したエステル類のメタノール中での $p K_{a}$ を塩酸および安息香酸を用いて測定した。以下その概略を述 ベる。

2.3.1 安息香酸による方法: エステル $\left(5 \times 10^{-4} \mathrm{~mol}\right)$ をメタノ 一ル $(50 \mathrm{~m} l)$ に溶かし，乙の液に安息香酸 $\left(7.5 \times 10^{-4} \mathrm{~mol}\right)$ を加兄 室温でかきまぜながら, ミクロビュレットを使用して水酸化ナト リウムメタノール溶液 $(4 \mathrm{~g} \mathrm{NaOH} / 100 \mathrm{~m} l \mathrm{MeOH}$ ) で逆滴定し た。その滴定曲線と, 空試験の滴定曲線との差から得られる解 離曲線の半当量点の $p \mathrm{H}$ の值を $p K_{a}$ とした。

2.3.2 塩酸による方法: 2.3.1 において，安息香酸のかわり に $1 \mathrm{~N}$ 塩酸 $0.6 \mathrm{ml}\left(6 \times 10^{-4} \mathrm{~mol}\right)$ を用い，他はすべて同様にして

2) 中島和雄，日化，81，499(1960).

3) 中帠和雄, 日化, 81, 962(1960).

4) 中島和雄, 日化, 81, 1129(1960).

5) A. Ladenburg, Ber., 14, 1877(1881).

6) Z. H. Skraup, Monatsh., 10, 390(1891).

*2 エステルの安息香酸塩を含むこともある.

7) 中村昭四郎, 有機合成化学, 24, 923(1966). $p K_{a}$ を测定した。

\section{3 実験結果および考察}

前記アえノェタノール類〔 1]〜[7]を Schotten-Baumann 法 によってベンゾィル化した場合に生成するエステル，無水安息香 酸，安息香酸の量を求省表 2 のようになった。

表 $2 N, N$ 二置換アミノェタノール $0.05 \mathrm{~mol}$ からの Schotten-Baumann 反応生成物

化合物 エステル 無水安息安息香酸 $p K_{a} 22^{\circ} p K_{a} 22^{\circ}$

$\begin{array}{lcccccc}\text { 化合物 } & (\mathrm{g}) & (\%) & \text { 香酸 }(\mathrm{g}) & (\mathrm{g}) & (\mathrm{HCl}) & \text { (安息香酸) } \\ {[1]} & 10 & (43) & 0 & 22 & 4.2 & a) \\ {[2]} & 13 & (58) & 0 & 15 & 3.1 & a) \\ {[3]} & 2.5(14) & 0 & 29 & 4.9 & a) \\ {[4]} & 14 & (60) & 2.3 & 20 & 7.3 & 7.6 \\ {[5]} & 4.0(28) & 10 & 11 & 6.6 & 7.2 \\ {[6]} & 5.5(33) & 12 & 3 & 7.2 & 7.6 \\ {[7]} & 5.0(29) & 6.6 & 15 & 7.1 & 7.8\end{array}$

注 $a$ ）エステルが存在するときの滴定曲線と空試験の滴定曲線 とが重なり測定不能であった。

表から明らかなように，〔1],〔2〕，〔3〕の場合, 反応生成物 は相当するエステルだけで，無水安息香酸は生成しなかった。し かし，〔4]，〔5]，〔6]，〔7〕の場合ではエステルと同時に無水 安息香酸も生成した。既報で述べたように，この反応で然水安息 香酸が生成するためには，エステルと安息香酸とが塩をつくるこ とが必要であるように思われる。この塩の生成の難易はエステル 中のアミノ基の塩基性と，置換基の立体障害とが関係しているよ うに思われるので，それを知る目安として，メタノール溶腹中で エステルに過剩に塩酸を加えてから，水酸化ナトリウムのメタ， 一ル溶液で逆滴定して求めた $p K_{a}$ と, 同様にして塩酸のかわり に安息香酸を用いたときの $p K_{a}$ とを測定し，表 2 に併記した。 塩酸を用いた $p K_{a}$ について見ると無水安息香酸の生成するエス テルでは，生成しないものにくらべ少し $p K_{a}$ が大きい。しかし， 安息香酸を用いた $p K_{a}$ では，両者間の違いはきわめて顕著とな り，無水安息香酸の生成するエステルでは $p K_{a}$ は 7.2 7.8で あったが，無水安息香酸のできないェステルでは，エステルの滴 定曲線と空試験の滴定曲線とが一致する。すなわち，エステルの 存在は安息香酸一水酸化ナトリウム滴定曲線になんらの影響をお よぼさない。このような差異は, 主としてアミンの塩基性に関倸 があるようであるが，立体障害む大きな役制を演じているように 思われるふしもあるので，その点を今後さらに検討する予定であ る。

表 3 生成エステル $\left(\mathrm{R}_{2} \mathrm{NCH}_{2} \mathrm{CH}_{2} \mathrm{OCOC}_{6} \mathrm{H}_{5}\right)$ の性質

\begin{tabular}{|c|c|c|c|c|}
\hline $\begin{array}{l}\text { 原料フミノ, } \\
\text { エタノール }\end{array}$ & 沸点 $\left({ }^{\circ} \mathrm{C} / \mathrm{mmHg}\right)$ & $n_{\mathrm{D}}{ }^{a)}$ & $\mathrm{N}$ 分 & $\begin{array}{l}\text { (計算值) } \\
\%)\end{array}$ \\
\hline$[1]$ & $232 \sim 234 / 2.5$ & $1.5790(14)$ & 4.03 & $(4.06)$ \\
\hline [2] & $227 \sim 228 / 2$ & - & 4.39 & $(4.33)$ \\
\hline [3] & $157 \sim 158 / 3$ & $1.5302(14)$ & 5.83 & $(5.96)$ \\
\hline [4] & $\left.213 \sim 215 / 2^{b}\right)$ & $1.5249(21)$ & 4.17 & $(4.26)$ \\
\hline$[5]$ & $107 \sim 108 / 2$ & $1.5036(22)$ & 7.25 & $(7.25)$ \\
\hline$[6]$ & $135 \sim 136 / 2$ & $1.5210(16)$ & 6.39 & (6.39) \\
\hline$[7]$ & $143 \sim 145 / 3$ & $1.5291(16)$ & 5.90 & $(6.01)$ \\
\hline
\end{tabular}

注 $a)\left(\right.$ )内は測定温度 $\left({ }^{\circ} \mathrm{G}\right)$ を示す。

b) $\mathrm{mp} 37^{\circ} \mathrm{C}$. 
なお，前記 Schotten-Baumann 反応で得られたエステルの性 質を表 3 によとめ。これらのエステルの赤外吸収スペクトルは $1720 \mathrm{~cm}^{-1}$ 付近と. $1050 \sim 1300 \mathrm{~cm}^{-1}$ に 2 本のエステルの特性吸 収を示し，また，窒素の分析值の結果も相当するエステルとして 計算した値といずれも一致した。

以上の実験結果を考察すると，第三級アミノ基を有する $N, N-$ 二置換アミノェタノール類の Schotten-Baumann 法によるベン
ゾイル化では，つねに無水安息香酸が生成するというわけではな く, 生成するエステルの塩基性と置換基の立体障害によって無水 安息香酸が生成するものと生成しないものとあることがわかっ た。なお，本実験においても，無水安息香酸の生成には，エステ ルの安息香酸塩の生成が重要な役割を持つととを示した。

(1967 年 4 月, 日本化学会第 20 年会諳演)
昭和 43 年 2 月 5 日 印刷 昭和 43 年 2 月 10 日 発行 発行兼編集人東京都千代田区(神田局区内) 神田駘河台 1 丁目 5 番地 印刷人東京都北区上中里町1 の 35 印刷所東京都北区 上 中里町 1 の 35 $\sim$
発 行 所東京都千代田区[神田局区内]神田駸河台 1 丁目 5 番地

社団 日 本 化 学 会 電話東京二貯金口座(東 京6058 番

(C) 1968 The Chemical Society of Japan
〔定価 300 円 (送料 30 円) ]

岩城広吉

倉 沢 直 則

株式会社双文社 